MLADEN JOVIČIĆ

904:666.3.04(497.11)”02/03”

Institute of Archaeology

COBISS.SR-ID 254091788

Belgrade, Serbia

E-mail: mladen_jovicic@yahoo.com

Original research article

BEBINA MILOVANOVIĆ

Received: May $16^{\text {th }} 2017$

Institute of Archaeology,

Belgrade, Serbia

\title{
ROMAN BRICK KILN FROM THE EASTERN NECROPOLIS OF VIMINACIUM
}

\begin{abstract}
During the construction of water supply network for the Viminacium archaeological park in 2013, the brick kiln on the site Pirivoj was discovered. More speciffically, the kiln was found on the eastern part of city necropolis. The biggest number of brick kilns at Viminacium was discovered on the southern city's necropolis during the 1980's, and three kilns were found at the site Pećine within the craft center. The newly discovered kiln at the site Pirivoj was built from unfired bricks and mud mortar, with a minimal use of brick. It belongs to the type of the combustion kiln with a single channel. The furnace chamber and grill kiln have been preserved to a greater extent, while the firing chamber was only partially conserved with walls in the height of $70 \mathrm{~cm}$. A vaulted firing port was located on the west side. Based on the layers within the kiln, two phases of use can be distinguished. Beneath the furnace chamber floor, an ancient well was found and which was used at the time before kiln was built. Based on small objects kiln is dated to the $3 r d$ century AD.
\end{abstract}

KEYWORDS: BRICK KILN, BRICK PRODUCTION, NECROPOLIS, PIRIVOJ, VIMINACIUM, $3^{\text {RD }}$ CENTURY AD.

\section{INTRODUCTION}

During the construction of water supply network for the Viminacium archaeological park in 2013, the brick kiln on the site Pirivoj was discovered. ${ }^{1}$ It presents the first brick kiln discovered on the eastern part of city necropolis, regarding that all other similar kilns were found on the southern city necropolis or on the area western from the Mlava River, at present day Kostolac

1 The article results from the project: Viminacium, Roman city and military camp - research of material and non- material culture of inhabitants by using the modern technologies of remote detection, geophysics, GIS, digitalization and $3 D$ visualization (no 47018), funded by The Ministry of Education, Science and Technological Development of the Republic of Serbia.
(Fig. 1). Although during the research no evidence about the owner of this brick was found, the position of brick, its dating, and specific construction led researchers to open new questions on brick work-activity at Viminacium.

\section{BRICK KILNS AT VIMINACIUM}

Viminacium is a roman city, situated on the right bank of Mlava River, near the confluence of Mlava and Dunav River, in close vicinity to present day Kostolac. Viminacium was formed in $1^{\text {st }}$ century AD as a military camp of legion VII Claudia, whereas subsequently civilian settlement 


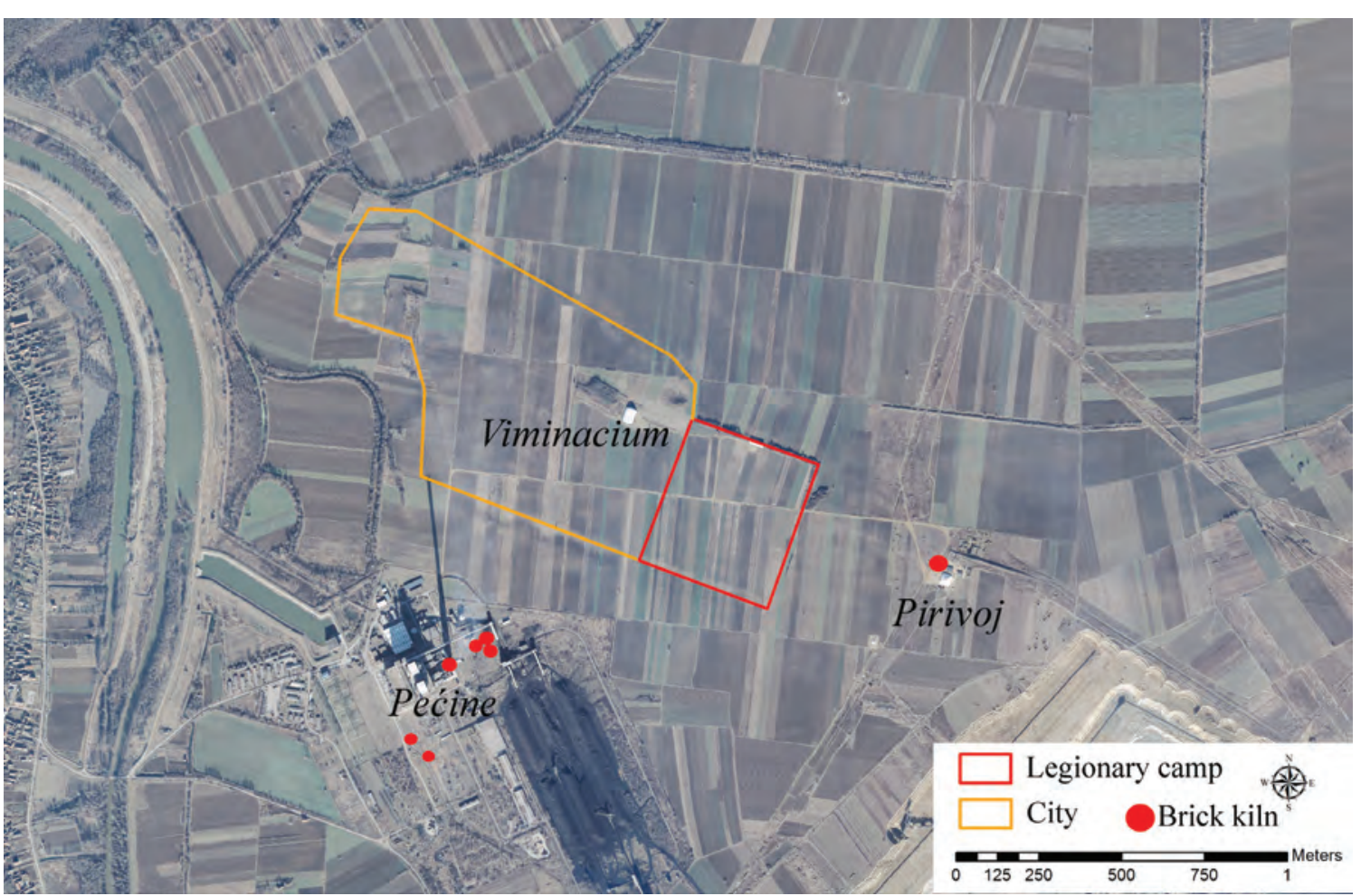

Fig. 1. Viminacium - location of excavated brick kilns.

emerged from the camp. It was the biggest city and the capital of Roman province of Moesia Superior, while in late Antique it becomes the capital of Moesia Prima (Спасић-Ђурић 2002: 21). At the time of Emperor Hadrian in 117 AD Viminacium obtained the status of municipium, while in $3^{\text {rd }}$ century AD the city was in full development, as it is evidenced by the fact that at that time, in 239 $\mathrm{AD}$ during the reign of Gordian III the city received status of colonia (Mirković 1986: 21-59; Спасић-Ђурић 2002: 25). Viminacium was devastated by Huns in 441 AD.

During many years of research, at the sites close to the city of Viminacium, 16 brick and 20 ceramic kilns have been discovered, which testifies that ceramic and brick production was very well developed at Viminacium. Since bricks were one of the main building materials in Antiquity, it is not surprise that the big number of brick kilns were found. The bricks from Viminacium are found throughout the territory of Moesia and a part of Pannonia, indicating that its consistent quality during the continuous production from $1^{\text {st }}$ to $4^{\text {th }}$ century $\mathrm{AD}$, production and trade were very well-organized (Спасић-Ђурић 2002: 121). The first three brick kilns were discovered in 1956 in Novi Kostolac (Ненадовић, Јуришић 1956: 129130). The kilns were arranged in a triangle, built on the same principle. ${ }^{2}$ Most of the brick kilns at Viminacium were discovered between 1977 and 1992, during protective excavations of the southern city's necropolis, at the area of Thermal power plant Kostolac B. As noted by Č. Jordović, in the area of the southern city's necropolis, at sites Pećine and Livade kod ćuprije 11 brick kilns and 14 ceramic kilns were discovered (Јордовић 1994: 96). However, not all kilns were published, only those from the area of Craftsmen center (Јордовић 1994: 96-104, ceramic kilns number 4-7 and brick kilns number 8-10). The Crafts-

2 During 2015 in Novi Kostolac, western from Mlava River, inside the Thermal power plant Kostolac A, a new brick kiln was discovered, which is preliminary dated to the late Antiquity. At the moment, researchers are analyzing the kiln and preparing it for publication. 


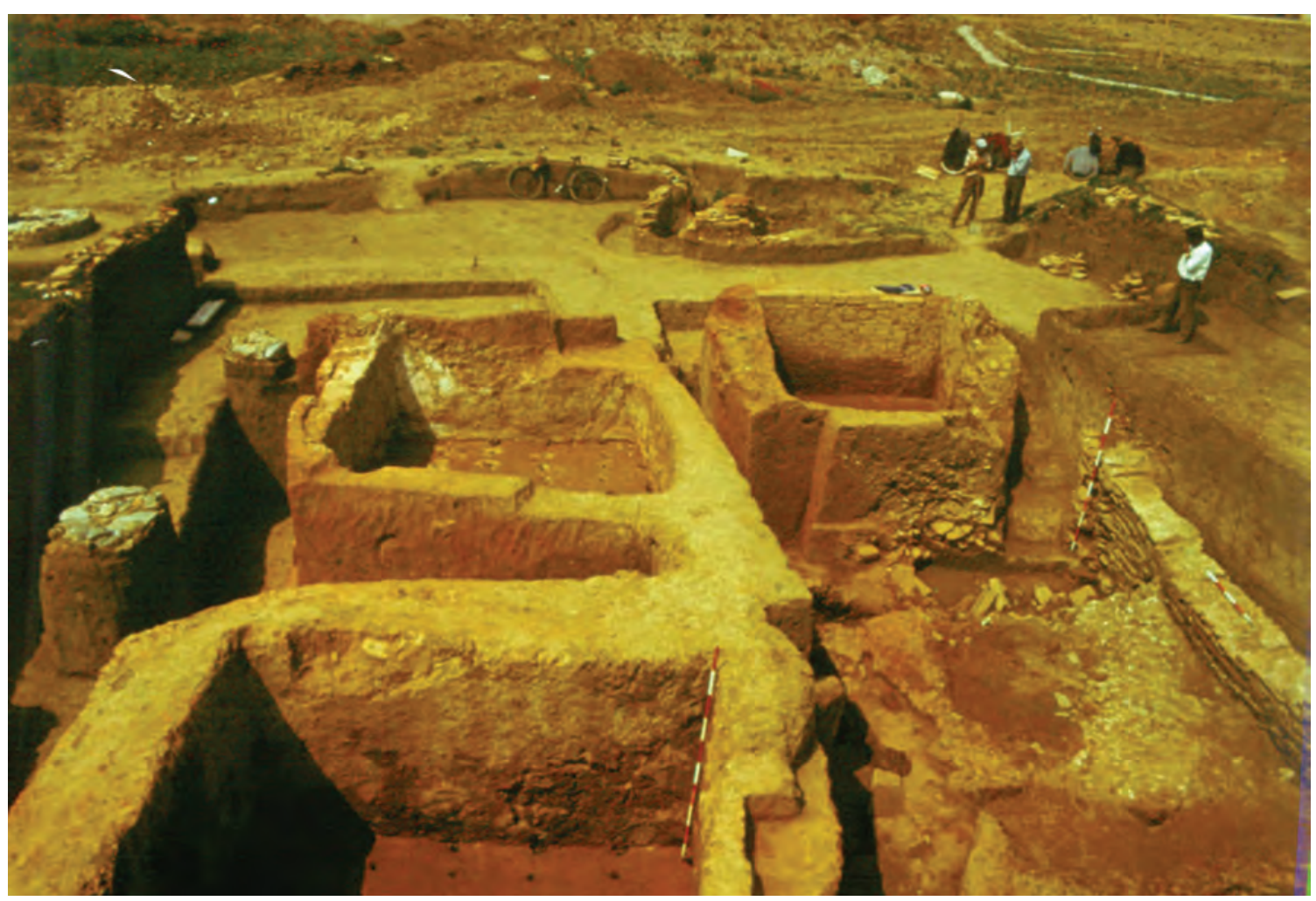

Fig. 2. Brick kilns from the craftsmen's centre on the site Pećine during the excavations (after Nikolić 2013: 28, Fig.12).

men center (ceramic-brick complex) consisted of three brick kilns and four ceramic kilns, a well, and a porch for the production and drying of the products, which were found in an area of about $700 \mathrm{~m}^{2}$ (Fig. 2). A. Raičković analyzed pottery from Craftsmen center and published another four pottery kilns from this area (Raičković 2007: 13, kilns number 1-3, 11). In the following years, three brick kilns and four ceramic kilns from the site Pećine were published (Raičković, Redžić 2006: 81-106). One brick kiln was found below the chimneys of today's thermal power plant Kostolac B, while two more were found near the early Christian memoria, Church A and Church B. All discovered kilns have been dated to the end of $2^{\text {nd }}$ and throughout $3^{\text {rd }}$ century. Since most of the kilns had brick stamp of Legia VII Claudia, they are interpreted as military kilns. Newly discovered kiln in 2013 at the site Pirivoj is the first brick kiln excavated in eastern necropolis, where so far only one ceramic kiln was found (Raičkov- ić, Vuković 2009: 7-11). Those studied ceramic kilns differ from brick kilns, since they were smaller with a basis circular in shape. However, the objects found inside the furnace chamber in some of the ceramic kilns showed that sometimes inside them bricks could be found or vice versa (Jeremić 2001: 133-134). Nevertheless, in this paper we will accept the traditional division and all the kilns with circular basis we will observe as ceramics, and all which are rectangular in shape will be observed as brick kilns. Since ceramic kilns are not the subject of this paper, they will not be further discussed.

\section{THE SITE PIRIVOJ}

The site Pirivoj is located eastern from the military camp of Legio VII Claudiae. The excavations of this site begin in 1997, and were intensifying in 2002-2007. At this area, a large number 
<smiles>NC(N)(F)S</smiles>

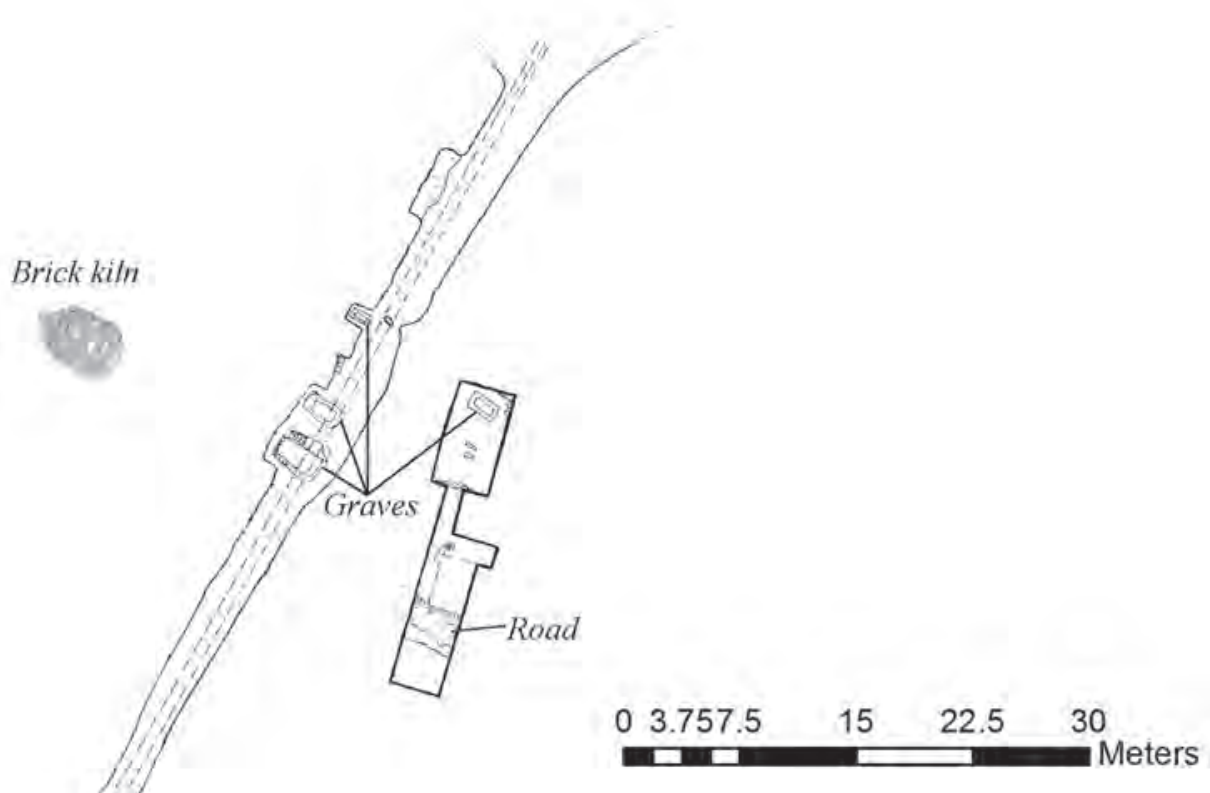

Fig. 3. Section of the site Pirivoj with position of excavated kiln, graves and road.

of graves have been discovered, which together with graves found at sites Kod Koraba and Nad Klepečkom belongs to eastern necropolis (Golubović, Korać 2015). The graves are dated to the end of $1^{\text {st }}$ century AD to the $4^{\text {th }}$ century AD. There are finds of cremations, inhumation burials in simple burial pits or burials in wooden or brick coffins (Golubović 2008; Redžić 2008), and one luxury fresco painted tomb (Korać 2007: 261, G 160). The most significant finding is the discovery of the mausoleum, which was built of large stone blocks and surrounded by a fence wall, dated to the middle of the $3^{\text {rd }}$ century (Korać, Golubović and Mrđić 2009: 91-95). An area southwest from the necropolis was investigated and based on small objects it is dated to the beginning of $2^{\text {nd }}$ to the beginning of $4^{\text {th }}$ century $\mathrm{AD}$ and interpreted as landfill of material from the sacrificial surface of the necropolis (Raičković, Milovanović 2010: 7-56; Vuković 2010: 57-82).

The newly discovered brick kiln was found $425 \mathrm{~m}$ from the eastern gate of the military camp, near the road that from the camp led to the east, to Veliko Gradište (Pincum) and which was also at- tested on the aerial photo. The road has been also confirmed by excavations and it is located in the immediate vicinity of the brick kiln, and the nearest graves are $12 \mathrm{~m}$ far from the kiln (Fig. 3). ${ }^{3}$ According to the reconstruction of road directions, the brick kiln was located only a few meters away from the road.

\section{THE NEWLY DISCOVERED BRICK KILN}

During the excavations in 2013 a brick kiln was discovered, with external dimensions $4.30 \mathrm{x}$ $3.60 \mathrm{~m}$, and height $2.30 \mathrm{~m}$ (Fig. 4, 5). ${ }^{4}$ The furnace chamber and grill have been preserved to a greater extent, while from the upper chamber only walls were partially conserved. The kiln was built from unfired bricks coated with mud, while the bricks were used only for arched elements of the furnace

3 Documentation of the Archeological Institute, project Viminacijum.

4 In order to investigate the kiln, a trench $5 \times 5 m$ was opened. The excavation team members were Mladen Jovičić, Bebina Milovanović, Svetlana Petaković and Ilija Danković. 


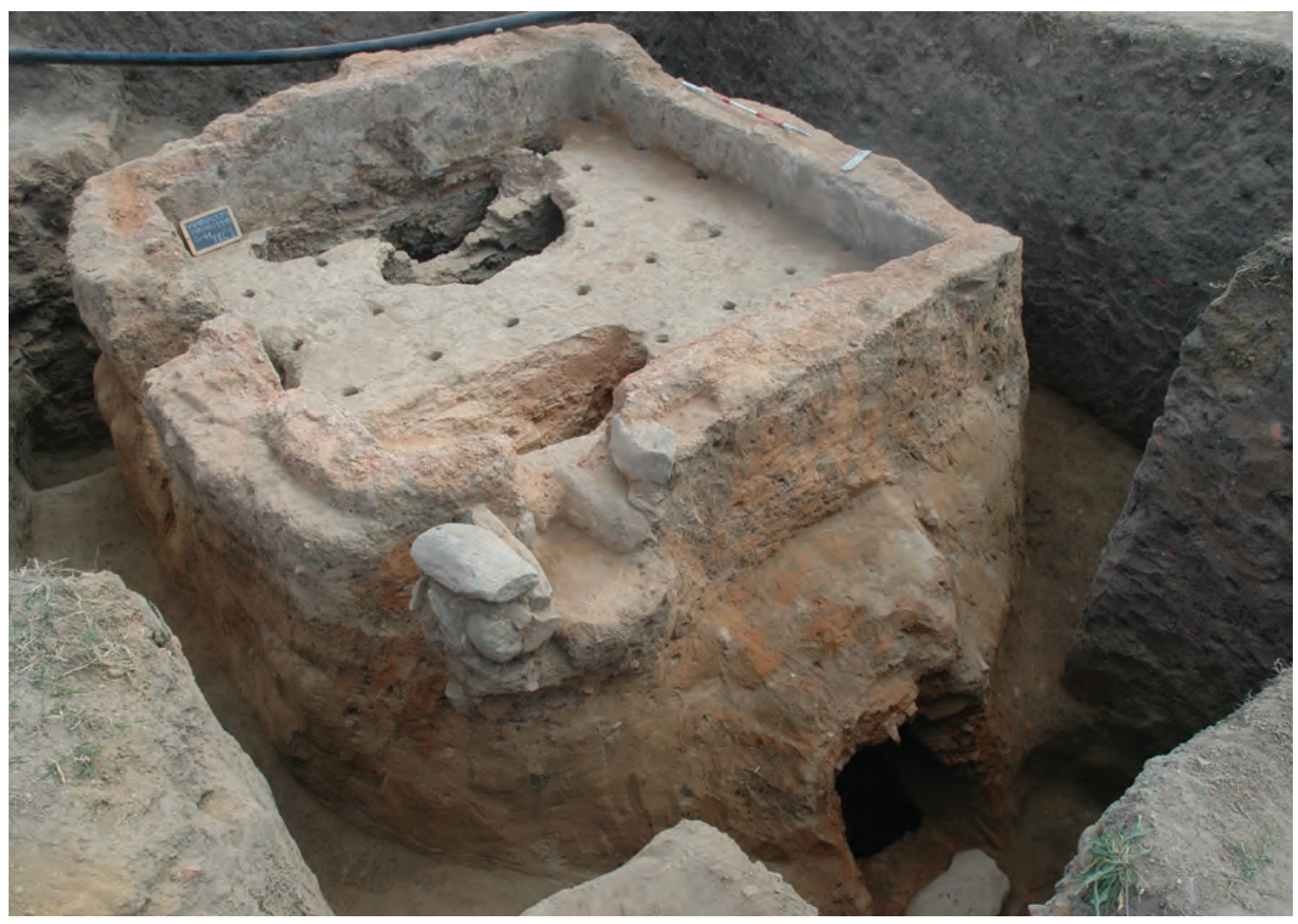

Fig. 4. Remains of brick kiln from the site Pirivoj.
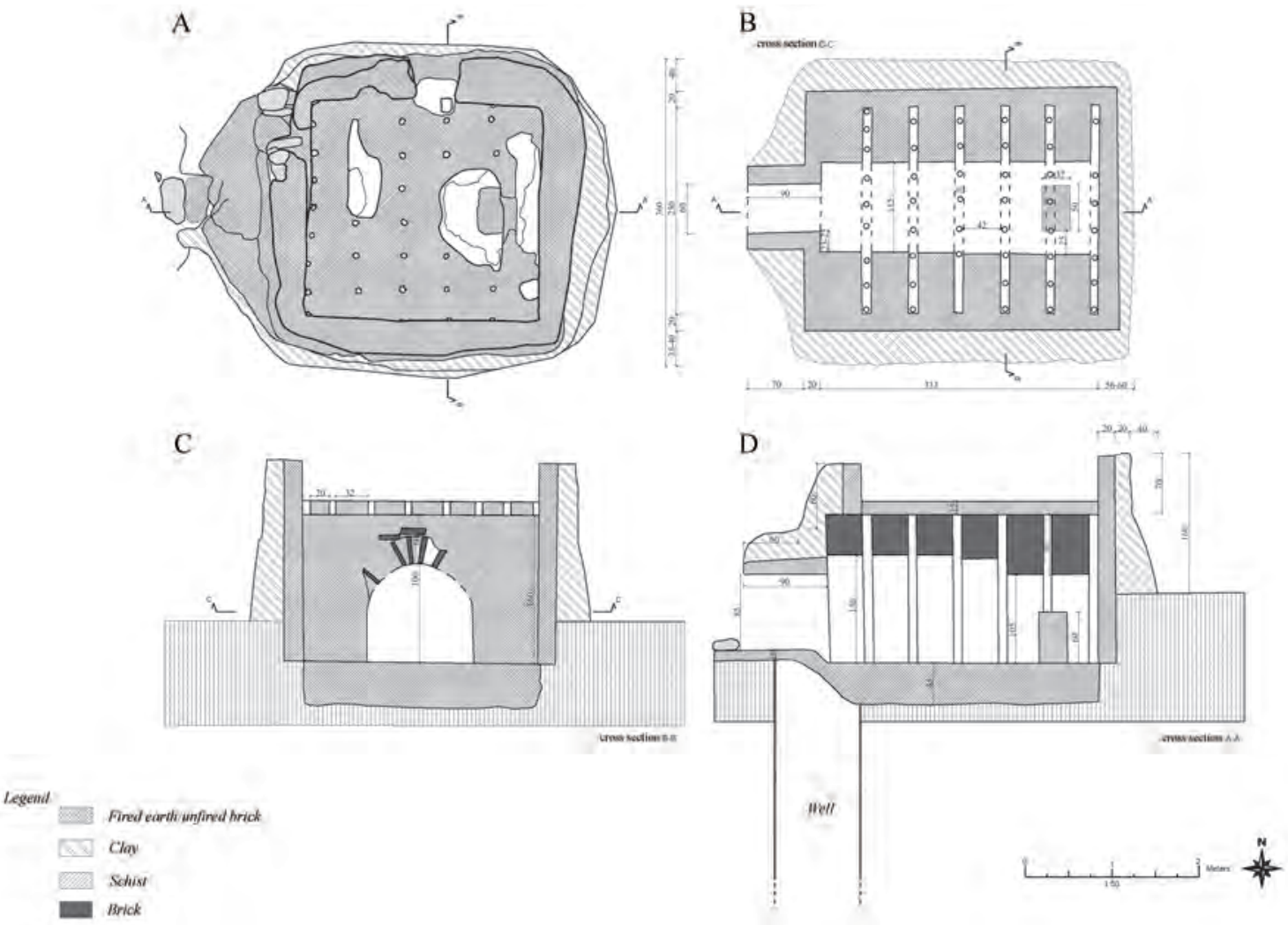

Fig. 5. Kiln: A) the plan of upper chamber with circular perforations (in the floor) for hot-air flow; B) plan of furnace-chamber with cross walls and tunnel; C) cross section; D) longitudinal section. 
chamber. It is oriented towards west-east with an opening to the west. The kiln is dug into $80 \mathrm{~cm}$ deep sterile soil and above it at $1 \mathrm{~m}$ into the cultural layer of $2^{\text {nd }}$ century AD. Since the kiln is located within the archaeological park where it will be presented to the public, it couldn't be deconstructed and the cross sections couldn't be made. Constructional parts of the kiln were reconstructed on the basis of external observations and according to the analogies with the so far explored kilns.

According to an ideal reconstruction, each kiln consists of: 1) prefurnium - furnace chamber with an opening, main tunnel and the side tunnels; 2) the grill - floor of the upper chamber on which unfired bricks were placed; 3) the upper chamber, where the baking process is carried out (Fig. 6). The bricks were first dried in the open air, and after they were placed on the floor of upper chamber, while the fire was stocked up in the lower chamber, and the hot air was circulated through the round opening of the grill to the upper chamber. Upon completion of stacking bricks, the upper lining of the kiln was coated with mud, and the dome or roof was formed (Jordović 1994: 103). The furnace chamber of kiln was dug into sterile soil, while the place for bricks was above ground, which is also the case with kiln from Pirivoj site. The upper chamber presents the place where baking of bricks was taking place. The chamber could have had a shape of dome or truncated pyramid (Jordović 1994: 104). On top of it there must have been an opening that improved air circulation. The chamber above the grill went to a height of $2 \mathrm{~m}$, which is the case with modern rural kilns in Požarevac region, as well as with the kiln from Pompei (Jeremić 2011: 151). Upon completion of the baking process, the roof covering was taking off and the bricks were extracted. At the next baking, the process was repeated and structural walls were coated with a new layer of clay (Raičković 2007: 15).

The remains of the upper chamber of the kiln from Pirivoj were found on the relative depth of 30 $\mathrm{cm}$ (Fig. 7). The height of the chamber walls was maximum $70 \mathrm{~cm}$. The dimensions of the chamber were $2.70 \times 2.50 \mathrm{~m}$. The walls were built of unfired bricks, with a $2 \mathrm{~cm}$ thick clay coat, of which three layers of coating were visible. The walls from unfired bricks were $20 \mathrm{~cm}$ thick, and their external surfaces were covered with 20-30 cm of clay. Small parts of the kiln walls mixed with soil, pieces of broken bricks, tegulae, imbrices, floor tiles and pottery fragments were found inside the upper chamber.

The kiln grill was formed with the layer of unfired bricks with a thickness up to $15 \mathrm{~cm}$, which were placed down on the pillars and arches of the furnace chamber. After burning the unfired bricks were merged into one monolithic structure. It had a $8 \times 6$ rows of holes for the flow of hot air (only the most western row had 9 holes), which were approximately $7 \mathrm{~cm}$ in diameter. The distance between the openings is $45-50 \mathrm{~cm}$ over a one axis, or $33 \mathrm{~cm}$ per second axis. On the grill two damages are visible: on the west the one recently formed due to construction of water supply network for the Viminacium archaeological park; on the east the big damage that was formed during Antiquity. Work kiln temperature was typically varied from 950 to $1000^{\circ} \mathrm{C}$. In the case when the temperature was higher than $1200^{\circ} \mathrm{C}$, it could cause vitrification, melting of unfired bricks and clay, which could therefore formed stalactites (Jeremić 2001: 152, note 67). This phenomenon was visible throughout the eastern half of the kiln, the grill and the pillars of the furnace chamber were damaged and melted, and larger pieces of grill were found inside the furnace chamber.

A vaulted firing port was placed on the west side (Fig. 8). The walls and barrel vault were made from the unfired bricks. The entrance had dimensions of $85 \times 60 \times 85 \mathrm{~cm}$. The floor of the opening was made of burnt clay, with thicknesses up to $20 \mathrm{~cm}$. At the vaulted construction the the clay layer was placed in the form of the calotte.

The furnace chamber consists of a central tunnel, orientated west-east, with dimensions $3.30 \mathrm{x}$ $1.15 \mathrm{~m}$, and the 6 side tunnels, orientated northsouth, with dimensions $70 \times 10 \mathrm{~cm}$, and with 


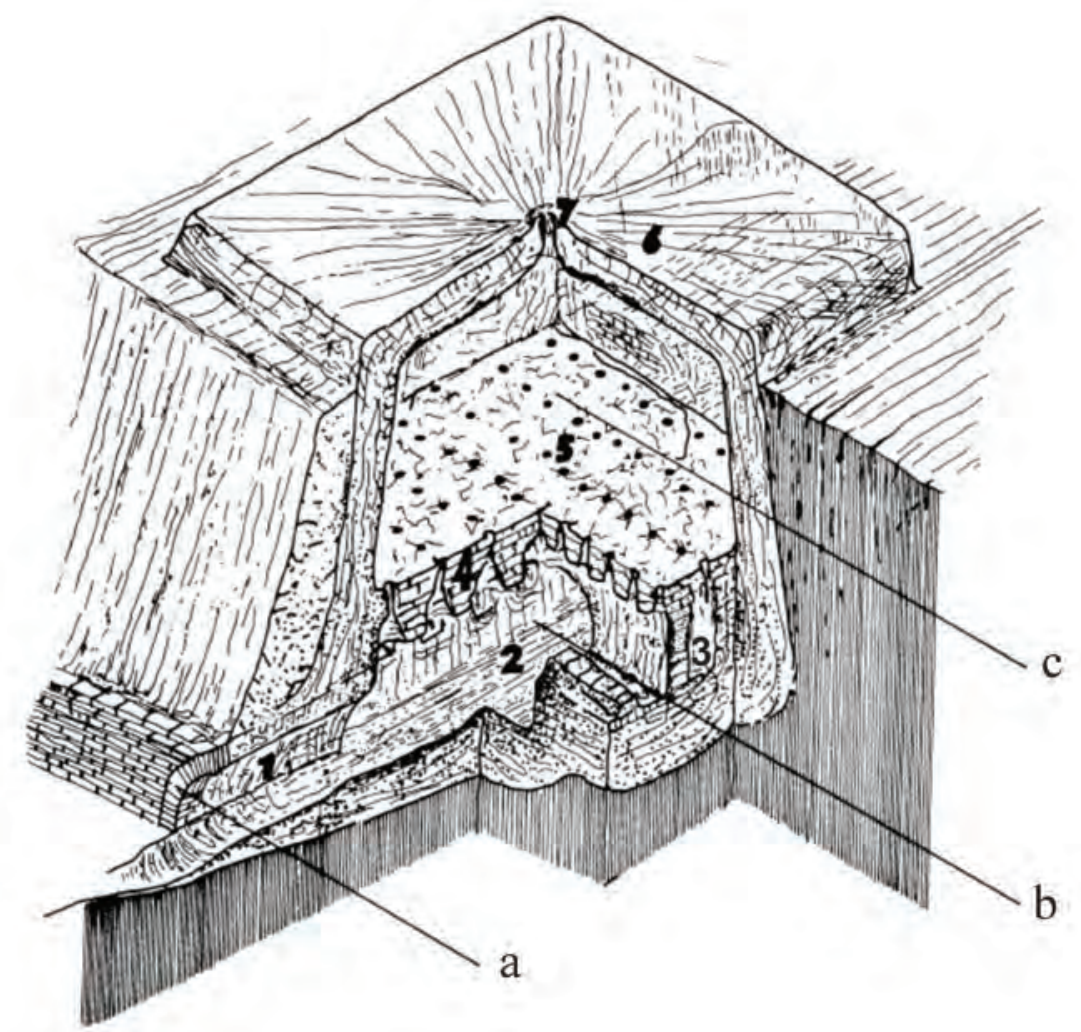

Fig. 6. The brick kiln - reconstruction: a) prefurnim; b) furnace-chamber; c) upper chamber; 1) vaulted firing port; 2) main tunnel; 3) side tunnel; 4) arch; 5) grill; 6) truncated pyramid roof of the upper chamber; 7) vent for smoke (after Јордовић 1994: 104, P1.3).

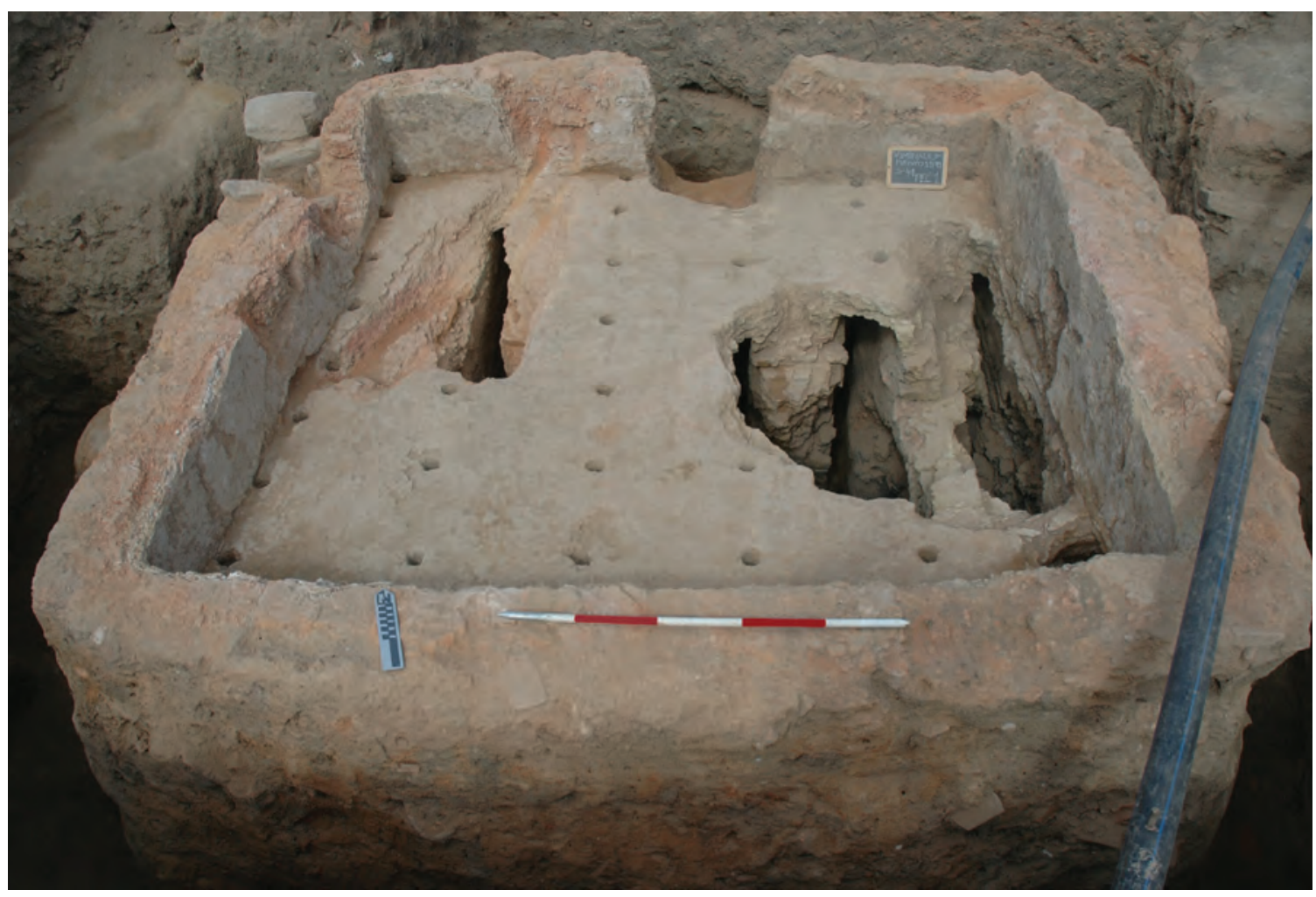

Fig. 7. Brick kiln from Pirivoj - remains of upper chamber and grill. 
height $1.60 \mathrm{~m}$ (Fig. 9). It was dig into the soil and was formed with six cross walls which were connected with arches and then formed a false vault. The height of central tunnel was $1.30 \mathrm{~m}$ on the west and $1.05 \mathrm{~m}$ on the east. The width of the cross walls is $42 \mathrm{~cm}$, and height from the floor to the grill was up to $1.60 \mathrm{~m}$. The arches between cross walls were formed with unfired bricks and tegulae bonded with clay. The space above the arch to the grill was filled with four layers of horizontal placed tegulae, which were also bonded with clay. In the eastern part of the central tunnel, between the fifth and sixth cross wall, there was a pillar made from unfired bricks. It had dimensions of 50 x 30 x $60 \mathrm{~cm}$. Since so far researchers didn't find any analogies, it has been hypothesized that its function was probably for better air circulation or that these pillar allowed less burning space which enabled higher temperature. Above this pillar, the damages of the grill, walls and arch were detected, probably caused by the highest temperature during the last use of the kiln. All the interior surfaces of the furnace chamber were lined with several layers of clay mixed with chaff.

The floor of the kiln was dig into the sterile soil. After burning, the layer of fired soil was formed, with the thickness of up to $45 \mathrm{~cm}$. During the excavations two levels of floor were detected (Fig. 10). After the burning, above the original floor, the first layer of hard gray ash, with a thickness of $3 \mathrm{~cm}$ was formed. Over this, the layer of compact soil, with the thickness of $18-20 \mathrm{~cm}$, was placed and on that way floor was leveled. The pieces of broken bricks mixed with clay were lined up and the second floor was formed. Above this floor, the second layer of ash was observed, with a thickness of $5-10 \mathrm{~cm}$. On the basis of this layers it is possible that the kiln was completely restored, which was also visible in the cross walls of the furnace chamber and the walls of the upper chamber which were lined with three layers of clay. It could be hypothesized that this kiln was used for a longer period, which is not uncommon, since the restoration were also noticed on the oth- er kilns found at Viminacium (Raičković 2007: 11-12; Jordović 1994: 100).

In front of the kiln opening there was a pit which was only partially excavated. The pit was spreading toward the west and it was deeper than the floor of the furnace chamber opening. By analogy with so far explored kilns at Viminacium, the pit had probably large dimension and was used initially as a source of clay, and then after as a working space and fuel deposit.

The biggest surprise during the excavations was a finding of roman well (Fig. 11). It was at the entrance to the furnace chamber, beneath the floor of burned soil. This well was in use at the time before the construction of the kiln; it is filled and probably forgotten before construction of the kiln. The well has a diameter of $1.0 \mathrm{~m}$, it is circular in shape, and it was dig into a layer of sterile soil. It is found at the relative depth of $2.5 \mathrm{~m}$ and excavated to a depth of $5.5 \mathrm{~m}$, after which excavations were stopped since there were no safe conditions for further diggings. It is filled with a dark soil in which the pottery fragments were found and dated to the $2^{\text {nd }}$ and the beginning of the $3^{\text {rd }}$ century AD. The well is important since it represents the terminus post quem for the dating of the kiln.

However, certainly when digging up the hole for the construction of the kiln, Roman craftsmen have come across a circular hole with different soil hardness and which was not stabile as the rest of the excavated area. It could be suggest that nevertheless they decided to fill up the well, and to build up a kiln above, since the digging of a new place would require a lot of time and effort. In addition to the well, next to the kiln two waste pits (pit 1 and 2) were found, which are dated to the period prior to its construction. 


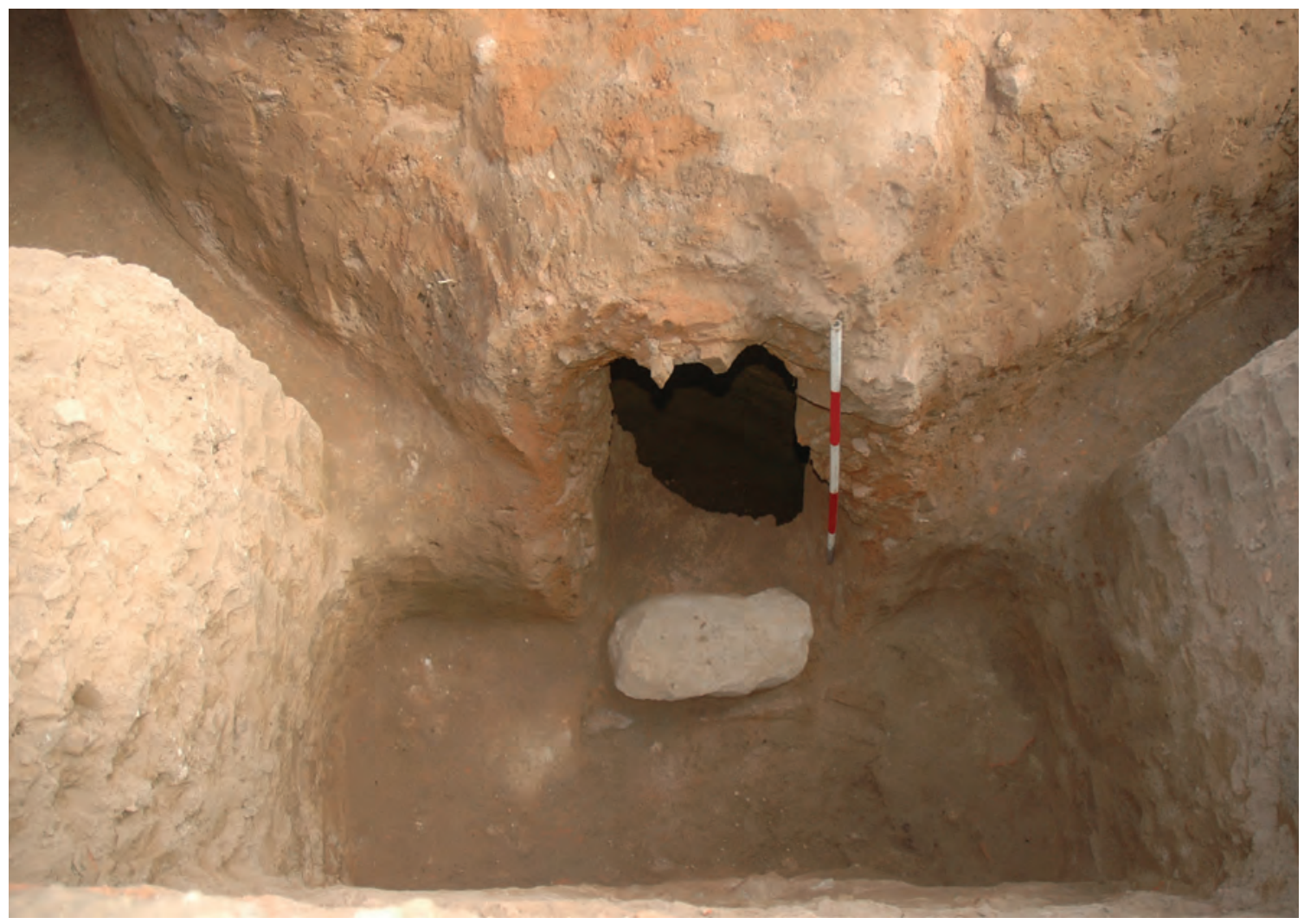

Fig. 8. Vaulted firing port and pit located western from the kiln.

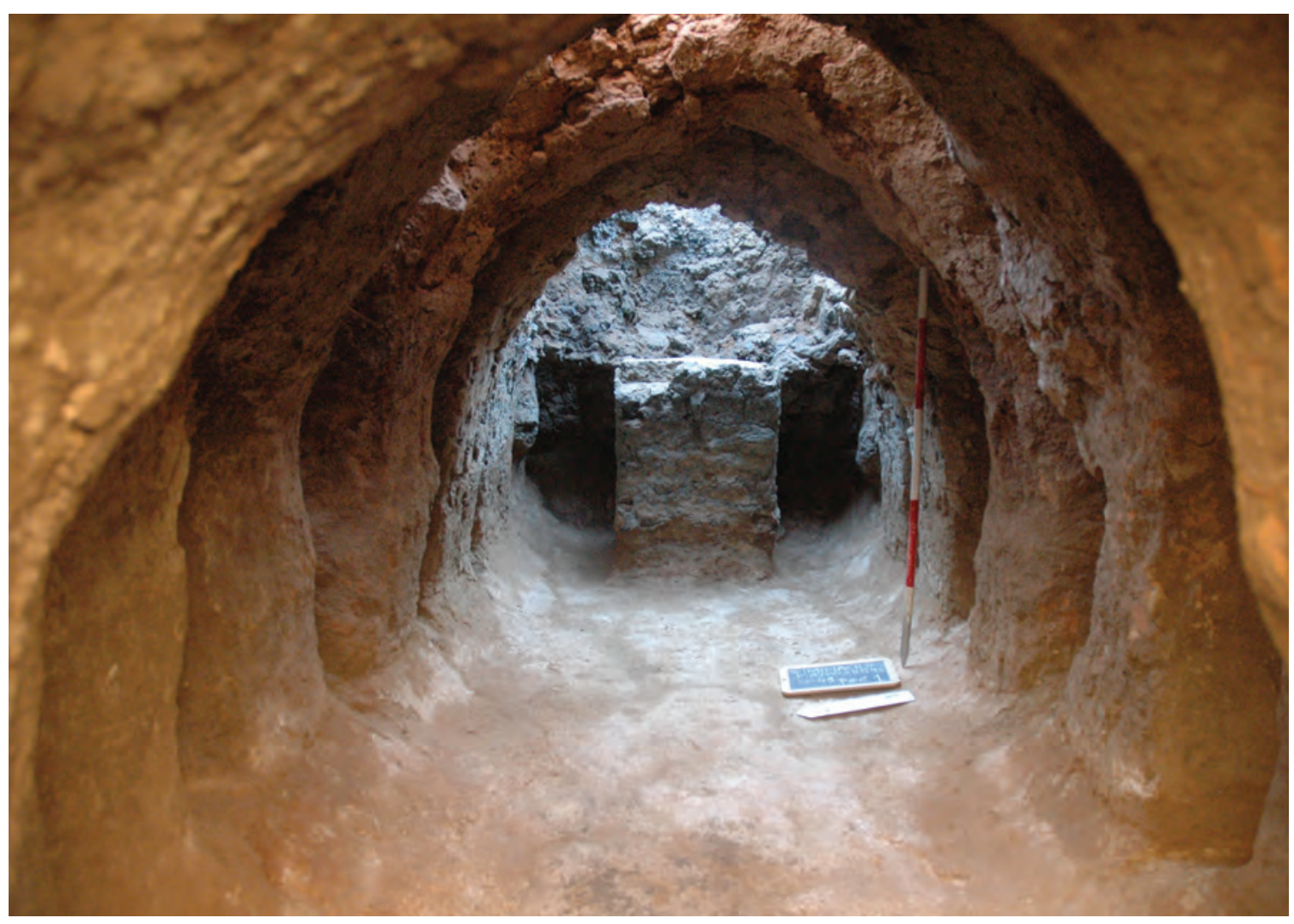

Fig. 9. Main tunnel and pillar in the east part of the kiln. 


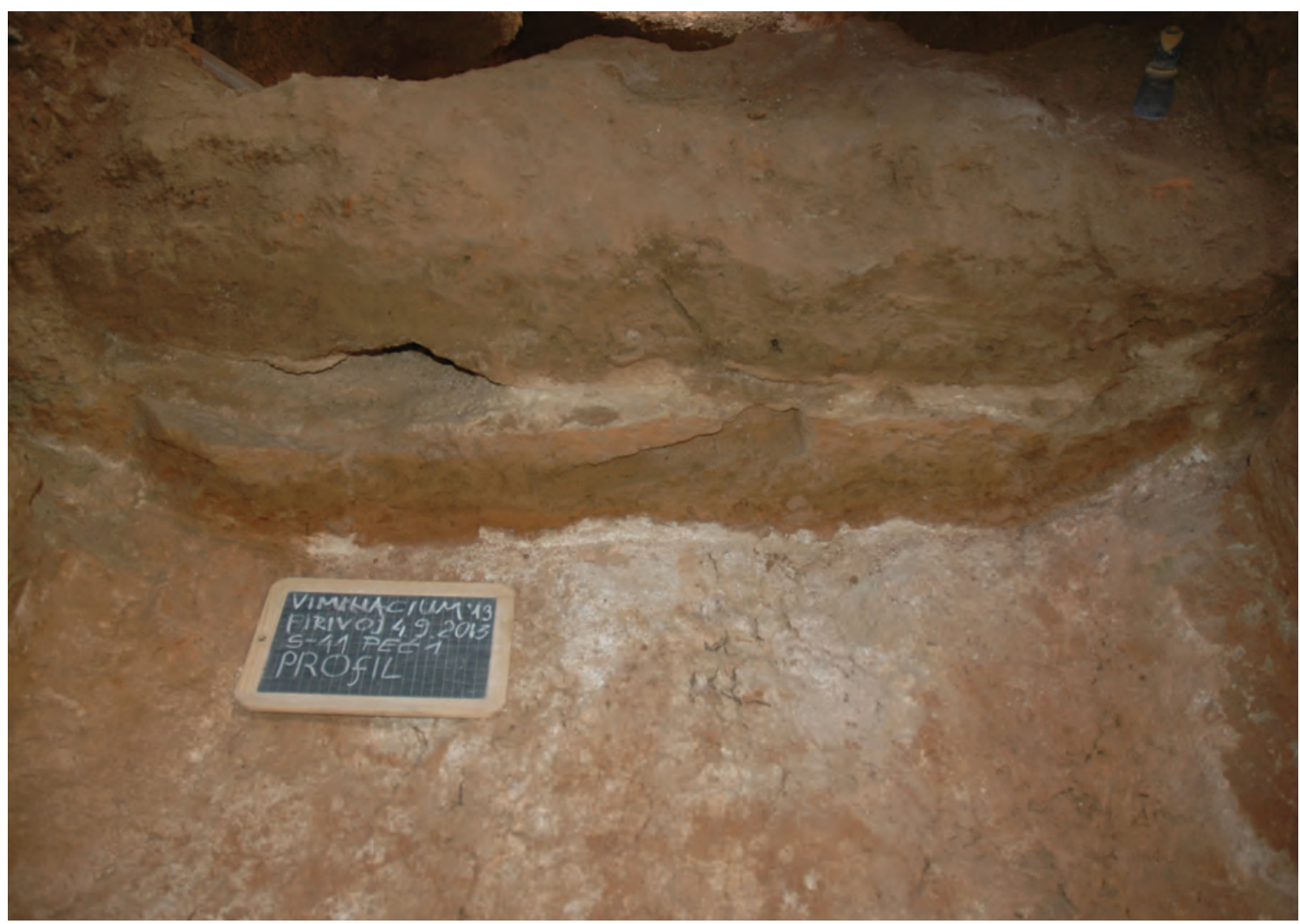

Fig. 10. Floor of the furnace-chamber with two layers of ashes above it.

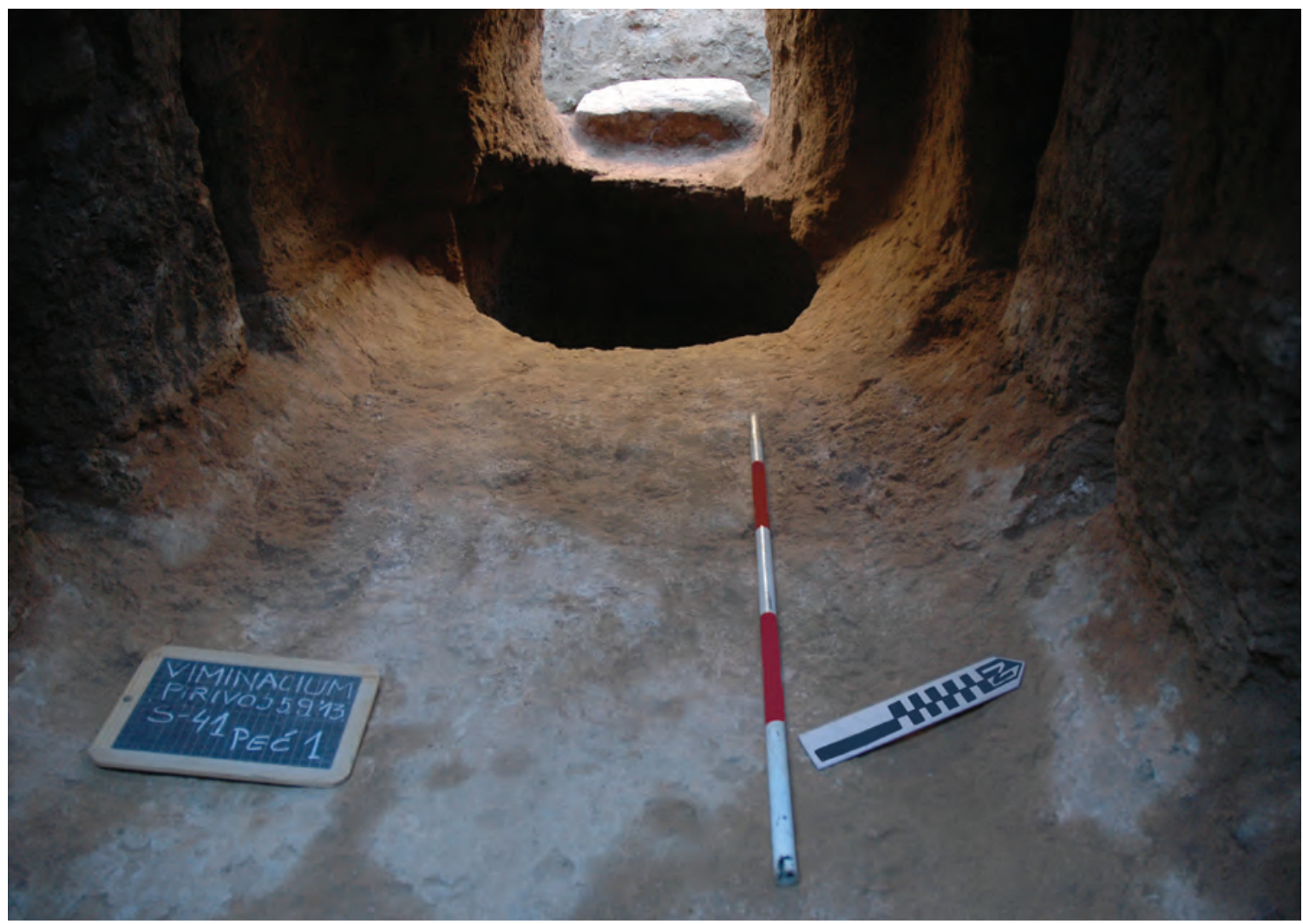

Fig. 11. Remains of well under the floor of the furnace-chamber. 


\section{THE FINDS}

A small number of movable finds were found in the cultural layer in which the kiln was placed and also from the pit 2, and they are presented in the Table 1 and 2. Among the metal finds, there were pieces of military equipment (fitting belt, strap terminal, circular application, part of the scale armor - lorica squamata). A fitting belt rectangular in shape (T. I. Fig. 1) has a profiled narrow ends in the form of pelta and a horizontally engraved fluting in the middle. Two perforations were used for fastening the leather strap. More than 50 copies of this type are known from the area of Upper Moesia and it is assumed that there was a produced center for this kind of fitting belt. Most of the examples from Viminacium were found in graves with coins of Hadrian. Therefore, it is considered that this period presents a beginning of its production, which continued until the end of the $2^{\text {nd }}$ century AD. Identical example was found at the same site and belongs to the type XVII / 4 (Pirivoj, C-559; Redžić 2013: 192, T. XLVI, Fig. 419). Part of the strap terminal (T. I. Fig. 2) is stored in the form of a double bent bronze band with two rivets for fastening the belt. From the pendant only a square ring is preserved, while the sword-shaped terminal is missing. The strips are atypical in shape, profiled in the middle and no direct analogies were found. This type is more common from the second quarter to the end of the $2^{\text {nd }}$ century $\mathrm{AD}$, although there are also finds from the late Antique period (Redžić 2013: 323, T. LXX, 812-814). One piece of the scale armour (lorica squamata; T. I. Fig. 3) was found in pit 2, which is older than kiln. This piece of equipment is often found in military camps along the middle and lower Danube (Vujović 2013: 32-33, Pl. I, 14, 36, Pl. III, 7). It has two perforations on both lateral sides and one the upper side. The lack of perforations which are used to connect scale with upper and lower rows, are dating this piece of armour in the first half of the $2^{\text {nd }}$ century AD (Radman-Livaja 2004: 79, 177-179, T. 28-30).
An intensely profiled bronze fibulae of so-called Black Sea- Danubian Basin type is mostly present in the territory of Upper Moesia. In Viminacium, there are over sixty examples of this type distributed in six variants. An example from the layer ( $\mathrm{T}$. I. Fig. 4) belongs to a third variant, characterized by a thickening of the bow, as well as wide flat foot. Fibulae of this type are dated to the end of the $1^{\text {st }}$ century to the middle of the $3^{\text {rd }}$ century AD (Redžić 2007: 25-26). Most of the other findings belong to chronologically insensitive material (the stylus, fragmented medical or cosmetic instruments, bone sewing needle, triangular arrowhead; T. I. Fig. 5-14).

Among the ceramic finds, lamps are dominated. The best preserved lamp (T. II. Fig. 15) was the one with two rounded and elongated nozzle with volutes. On the disk rosette is depicted. It has leaf-shaped handle, while the base is formed in the shape of a ring. On the territory of Viminacium these examples are dated from the period of Tiberius to Septimius Severus (Korać 1995: 76-80). According to the typology fragmented lamps (T. II. Figs. 16-19) belong to type with a rounded-nozzle. These examples are the most common finds in almost all the Roman provinces, and also in Viminacium where these lamps are the most numerous after the lamps with stamps (firma lamp). With a number of variants and the sub-variants, this type of lamps in Viminacium is chronologically determined to the first decades of the $1^{\text {st }}$ century until the first half of the $3^{\text {rd }}$ century AD (Korać 1995: 116). The fragmented lamp (T. II. Fig. 16) with deep body and flat base, has the shape of little bowl, and such forms are typical for late Antiquity (the end of the $3^{\text {rd }}$ and beginning of $4^{\text {th }}$ century), and are often covered with enamel, although there are exceptions, such as the above mention example.

Other ceramic finds comprises two irregularly objects, circular in shape, made of clay. The object with the smaller diameter (T. II. Fig. 20) could be used to seal the holes on the grill of the kiln, due to the corresponding diameter. The second 
object of a larger diameter (R-13.2 cm; T. II. Fig. 23) could be used for different purposes (weight, floor tile, cover, etc...), and thus its function remains unknown.

The fragmented find made of burnt clay ( $\mathrm{T}$. II. Fig. 21), circular in shape with relief radial lines (spokes) on the one side, and the central perforation, represents a wheel of a children's toy (Raičković, Redžić, Rogić 2006: 79, 83, T II, Fig. 11; Premk 1994-1995: 143-155, Fig. 8). The part of the roman terracotta figurine with remains of white engobe represents female thighs with the remains of the legs. Only the front side of figurine is preserved and it was made in mold (T. II. Fig. 22). One can assume that it is a figurine of the goddess Venus. The terracotta figurines are numerous in Viminacium and are assumed to present cheap replacement for figurines made from stone or metal. Those figurines could have had multiple purposes. They were used as votive offering in temples and home chapels and were placed in the graves as a cult objects. The terracotta goddess figurines are often present in funeral deposits and are usually associated with Venus Funeraria (Јовановић 2000: 13-14, 18). However, some of them were also used as a toy (Raičković, Redžić, Rogić 2006: 78, 82, T. I. Fig. 1-5; Pejović 1995: 37-62; Veličković 1957).

During the research of kiln a small amount of pottery fragments was found. ${ }^{5}$ The pottery from the layer in which the kiln was dig into is dated to the $2^{\text {nd }}$ century, and pottery fragments from the well are dated to the $2^{\text {nd }}$ and the beginning of $3^{\text {rd }}$ century. The same case is with above mentioned small finds from the layer, well and pit 2. Small fragments of pottery dated to the beginning of the $4^{\text {th }}$ century were found in the rubble inside the kiln, when the kiln was out of use. Thus, the use of the kiln can be dated somewhere between third decade of the $3^{\text {rd }}$ century and to the first/second decade of the $4^{\text {th }}$ century.

5 The authors are grateful to Snežana Nikolić and Ana Bogdanović, who analyzed pottery finds.

\section{DISCUSSION}

This is single tunnel kiln, rectangular in shape, of a standard type (Normaltyp according to Berger), which has been dated to the Roman Imperial period until 260 year AD (Berger 1969: 32). Most of the kilns from Viminacium belongs to this type, such as the kilns from Craftsmen center or the other kilns from Pećine, which are dated to the $2^{\text {nd }}$ and $3^{\text {rd }}$ century AD (Jordović 1994: 99-101; Raičković, Redžić 2006: 84-85). However, such kilns in our region appeared after $260 \mathrm{AD}$, such as the case with kiln of the same type from Čukujevac near Kraljevo, which is dated to the end of the $3^{\text {rd }}$ century AD (Љамић-Валовић 1985: 21-30); the five kilns from Sirmium dated to the $3^{\text {rd }}$ and $4^{\text {th }}$ century (Jeremić 2001: 144-148, kilns no. 3-7); kilns from Stalać and Bakionica from the $4^{\text {th }}$ century AD (Минић 1991: 313; Бућић, Петровић 1984: 8-15). Therefore, the kiln from Pirivoj dated to the $3^{\text {rd }}$ and the beginning of the $4^{\text {th }}$ century AD is not an exception. At Viminacijumu there are also examples of doubled-tunnelled kiln (Zweikammertip (Berger 1969: 18)). That kiln was found beneath the chimney of Thermal Power plant Kostolac B (Raičković, Redžić 2008: 85-86, the furnace no. 3 ), and is similar to two kilns from Sirmium (Jeremić 2001: 141-144, furnace no. 1 and 2).

The construction and dimensions of kiln from Pirivoj are similar the the other kilns excavated in Viminacium. Based on the size it belongs to kilns of medium size. The only unusual detail is pillar in the eastern part of the central furnace chamber and so far there are no analogies. All the interior surfaces of the furnace chamber were lined with several layers of clay mixed with chaff, such as the case with other kilns at Viminacium (Raičković, Redžić 2008: 85) or Stalać (Минић 1991: 310) and Sirmium (Jeremić 2001: 143-148). The thickness of the grill of this kiln is $15 \mathrm{~cm}$. The average thickness of the grill from kilns found in Hungary and Germany was from 8 to $20 \mathrm{~cm}$, while in the kilns from Serbia, Slovenia and Albania is from 30 to $37 \mathrm{~cm}$ (Jeremić 2001: 150), so this grill from 


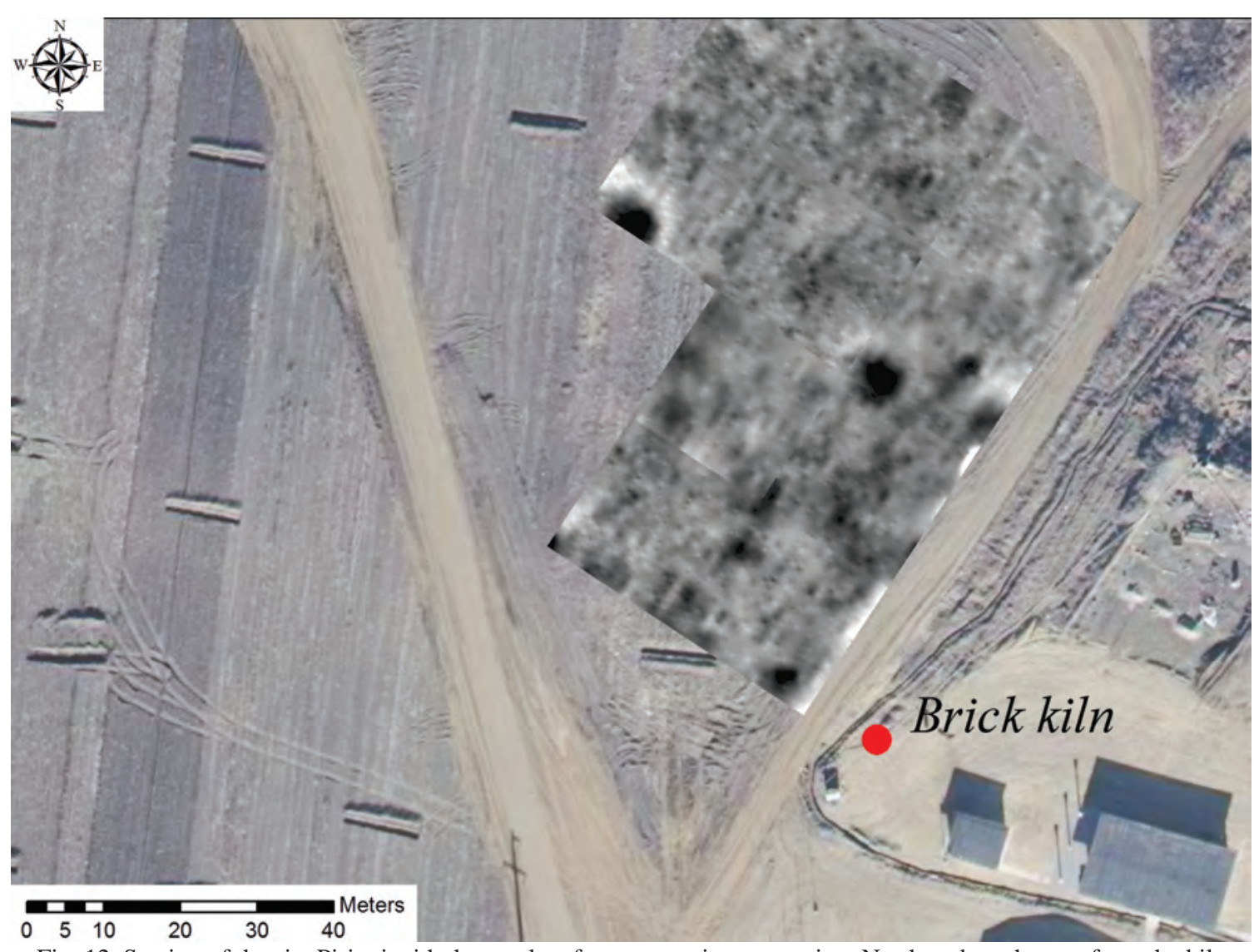

Fig. 12. Section of the site Pirivoj with the results of geomagnetic prospection. North and north-west from the kiln there are anomalies with high magnetic value, which could present remains of the kilns (documentation of Center for New Technology Viminacium).

Pirivoj belongs to thinner. As mention above, a high temperature in the eastern part could cause vitrification, melting of grill and walls (Jeremić 2001: 152, note 67). This phenomenon is noted in the Late Antique kiln from the site Progarski vinogradi in Srem, where scholars considered that the temperature, which caused destruction of the kiln, could be around $1500^{\circ} \mathrm{C}$ (Dimitrijević 1969: 108). The similar situation is observed for kiln No. 3 from Sirmium, where the temperature was $1200^{\circ} \mathrm{C}$ (Jeremić 2001: 152, note 67, Fig. 18).

The discovery of this kiln raises several questions. First, is it an isolated kiln or it was a part of new Craftsmen center? As seen above, in the case of Viminacium (Jordović 1994), Sirmium (Jeremić 2001) and Stalać (Минић 1991: 314), the kilns are usually made in pair or even more and are part of workshop complex. Workshops were widespread throughout Upper Moesia and in addition to Vi- minacium, it is considered that the workshops for making bricks existed in Singidunum, Margum, Pincum, Cuppae, Bononia, Diana and Aquae (Mirković 1968: 130-142). This part of the necropolis has not been yet fully explored, but the results of the geomagnetic prospection shows a strong anomaly in the vicinity, so one cannot exclude the possibility that there are more kilns, and that this kiln is part of a Craftsmen center (Fig. 12). ${ }^{6}$

The second question remains open, since the builder or the owner of the kiln is unknown. Roman kiln could be private, military and imperial. In the roman province of Upper Moesia precedence in the production of bricks had military brickyards, and the largest number of bricks was produced in the workshops of the legion VII Claudia (Jevtović

6 Geomagnetic prospection was done by experts from the Center for new technology Viminacium. The authors would like to thank Vladimir Miletić for this data. 
2013). The brick stamps of this legion were found in the kilns from Craftsmen center, which is also attributed to this military unit and identified as a military workshop (Jordović 1994: 95). Although brick of the military workshop are dominating, bricks with stamps from private workshops were also numerous at Viminacium (Mirković 1968: 141; Spasić-Đurić 2002: 144). Concerning the kiln from Pirivoj, there were no findings of bricks with stamps, probably because the cross section of the kiln was not made, since the kiln is supposed to be presented to the public within Archaeological Park. However, the vicinity of military camp supports the hypothesis that the builders and owners of the kiln could be legionnaires of VII Claudia.

The brick workshops were built outside the urban zones, since outbreak of fire was highly possible and because of more space for work. Furthermore, the proximity to water resources and the quality clay land were very important for these workshops. Kilns from the area south of the city were situated near the necropolis, and this location was abundant of quality soil and located near the Mlava River, although the well was found within the Craftsmen centre (Jordović 1994: 95-96). The kilns from Sremska Mitrovica were also found at the necropolis (eastern necropolis of Sirmium (Jeremić 2001: 131)). Therefore, it is not unusual that kiln from Pirivoj was also found in the eastern necropolis. At Pirivoj a well was also found, which belongs to the phase before the construction of kiln. Since the trench was of smaller dimensions, the remains of well which could be used for the purpose of the kiln, if any, couldn't be fully excavated. Anyhow, it can be assumed that in close vicinity there was well or more of them (since it was far from the river) as indicated by the ground water source, documented at this location. Concerning the raw materials, it can be noted that in rural areas around Požarevac kilns of similar construction still exist, and Stig region is known for high-quality clay for bricks (Jeremić 2001: 151, Fig. 30-35). Roman clay pits are found at several Viminacium sites, and the nearest was at site
Rit, which is located $1 \mathrm{~km}$ north from this kiln. ${ }^{7}$ At the end of the $19^{\text {th }}$ century Mihajlo Valtrović noted that east from Pećine, at the site Korabe, there was a big clay pit for bricks, which local inhabitants used as building material and considered to have been used by the Romans (Валтровић 1884: 98-99). Based on these findings, one can conclude that Pirivoj was abundant with the quality raw materials. Furthermore, the proximity of communication was very useful for delivering products to the market, and as mention above the communication was very close to the kiln.

\section{CONCLUSION}

The brick industry at Viminacium was very active during the entire antique period, from the $1^{\text {st }}$ to the end of the $4^{\text {th }}$ century AD (Jordović 1994: 105). The kiln from Pirivoj is important since it is constructed above the well, used in the $2^{\text {nd }}$ and beginning of $3^{\text {rd }}$ century $\mathrm{AD}$, while the pottery finds from the rubbish are dated to the beginning of the $4^{\text {th }}$ century AD. Therefore, the use of the kiln can be placed to the middle and the second half of the $3^{\text {rd }}$ century $\mathrm{AD}$. It exists at the time of the most intensive development of the city and burying at the necropolis. It is dated to the similar time, as is the case with kilns from Craftsmen center at the south necropolis. This kiln is significant since it could be evidence for new, so far unknown Craftsmen centre.

\section{THE CATALOGUE}

1. A fitting bronze belt rectangular in shape with a profiled narrow ends in the form of pelta and a horizontally engraved fluting in the middle. Two perforations were used for fastening the leather strap. Dimensions: $5.2 \times 1.8 \mathrm{~cm}$. In the layer, relative depth $60 \mathrm{~cm}, \mathrm{C}-1302$.

7 Clay deposit, used as a source for raw material throughout the $2^{\text {nd }}$ century $\mathrm{AD}$, was filled in $3^{\text {rd }}$ century AD (Danković, Petaković 2014: 61). 
2. Part of the strap terminal stored in the form of a double bent bronze band with two rivets for fastening the belt. From the pendant only a square ring is preserved, while the swordshaped terminal is missing. In the layer, relative depth $110 \mathrm{~cm}, \mathrm{C}-1304$.

3. One piece of the bronze scale armour (lorica squamata) with two perforations on the both lateral sides and one the upper side. Dimensions 4.5 x $2 \mathrm{~cm}$. Pit 2, C-1310.

4. An intensely profiled bronze fibulae characterized by a thickening of the bow, as well as wide flat foot. Length $4.6 \mathrm{~cm}$. In the layer, relative depth $60 \mathrm{~cm}, \mathrm{C}-1303$.

5. Silver application circular in shape decorated in repoussage technique. Diameter $2.2 \mathrm{~cm}$. In the layer, relative depth $120 \mathrm{~cm}, \mathrm{C}-1305$.

6. Fragment of bronze medical instrument profiled at one end. Length $2.8 \mathrm{~cm}$. In the layer, relative depth $40 \mathrm{~cm}, \mathrm{C}-1315$.

7. Fragment of bronze stylus. Only the flat, semi-circular end is preserved. Length $4.4 \mathrm{~cm}$. In the layer, relative depth $120 \mathrm{~cm}, \mathrm{C}-1318$.

8. Fragment of bronze item rectangular in shape, with strip intersection. Dimensions $6.3 \times 1.9$ $\mathrm{cm}$. In the layer, relative depth $145 \mathrm{~cm}, \mathrm{C}-1322$.

9. Fragmented iron triangular arrowhead. Length $3.3 \mathrm{~cm}$. In the layer, relative depth $40 \mathrm{~cm}$, C-1316.

10. Fragmented bronze instrument with thickened end. Medical or cosmetical instrument. Length $10.5 \mathrm{~cm}$. In the layer, relative depth 2 $\mathrm{m}, \mathrm{C}-1313$.

11. Bronze sewing needle with rectangular loop. Length $13 \mathrm{~cm}$. In the layer, relative depth 150 cm, C-1320.

12. Fragmented sewing needle with perforations on the top. From pit 2, C-1311.

13. Fragment of bronze chain. In the layer, relative depth $125 \mathrm{~cm}, \mathrm{C}-1317$.

14. Miniature hexagonal green glass bead. Length $0.5 \mathrm{~cm}$. In the layer, relative depth $90 \mathrm{~cm}$, C-1301.

15. The lamp with two rounded and elongated noz- zle with volutes. On the disk rosette is depicted. It has leaf-shaped handle, while the base is formed in the shape of a ring. Red baked clay. The diameter of the disc is $8.9 \mathrm{~cm}$, the diameter of base is 4.4 , height is $8.9 \mathrm{~cm}$. In the layer, relative depth $160 \mathrm{~cm}, \mathrm{C}-1307$.

16. The ceramic lamp with deep body and flat base. The disc and nozzle are fragmented. The handle is horizontal with perforation circular in shape. Red baked clay. The diameter is 6 $\mathrm{cm}$. From the layer, C-1308.

17. The ceramic fragmented lamp with flat base and strip handle. Red baked clay. The diameter of the basis is $3.4 \mathrm{~cm}$, height $3.9 \mathrm{~cm}$. In the layer, relative depth $160 \mathrm{~cm}, \mathrm{C}-1309$.

18. The ceramic lamp with concave disc and concentric circles. The nozzle is fragmented. It has strip handle. Red baked clay. The diameter of the disc is $7.1 \mathrm{~cm}$, the diameter of the basis is $2.9 \mathrm{~cm}$, height $4.5 \mathrm{~cm}$. In the layer, relative depth $150 \mathrm{~cm}, \mathrm{C}-1319$.

19. The flat basis of ceramic lamp with fragmented deep body. The disc has not been preserved. The fragment of the handle is preserved. Red baked clay. The diameter of the basis is $3.8 \mathrm{~cm}$. In the layer, relative depth $160 \mathrm{~cm}, \mathrm{C}-1321$.

20. The ceramic item circular in shape (perhaps used as a cover for grill holes?). The diameter $7.9 \mathrm{~cm}$. In the layer, relative depth $125 \mathrm{~cm}$, C-1323.

21. The fragment of ceramic toy wheel, circular in shape with relief radial lines (spokes) on the one side. Red baked clay. The semi-diameter is $3.3 \mathrm{~cm}$. In the layer, relative depth $120 \mathrm{~cm}$, C-1306.

22. The part of the roman terracotta figurine represents female thighs with the remains of the legs (the goddess Venus?). Red baked clay with remains of white engobe. Length $7.2 \mathrm{~cm}$; width $3.7 \mathrm{~cm}$. In the layer, relative depth 120 cm, C-1324.

23. The ceramic item circular in shape. Red baked clay. The diameter $13.2 \mathrm{~cm}$. In the layer, relative depth $240 \mathrm{~cm}, \mathrm{C}-1314$. 


\section{BIBLIOGRAPHY}

Berger, L. 1969

Ausgrabungen in Augst III - Ein römischer Zigelbrennofen bei Kaiseraugst, Basel.

\section{Бућић, Ј. Петровић, П. 1984}

Римске цигларске пећи и вила у Бакионици код Пожеге, Ужички зборник 13: 5-22.

\section{Danković, I., Petaković, S. 2014}

Istraživanja na lokalitetu Rit (Viminacijum), u: V. Bikić, S. Golubović, J. Anđelković Grašar (ur.) Arheologija u Srbiji: projekti Arheološkog instituta $u$ 2013. godini: 60-63.

\section{Dimitrijević, D. 1969}

Istraživanje rimskog limesa u istočnom Sremu s posebnim osvrtom na pitanje komunikacija, Osječki zbornik XII: 81-121.

Golubović, S. 2008

Археолошка истраживања на локацији Пиривој, Виминацијум, Археолошки Преглед 4 (2006): 95-98.

\section{Golubović, S., Korać, M. 2015}

Eastern Necropolis of Viminacium - Latest Excavation. In: Limes XXII. Proceedings of the $22^{\text {nd }}$ International Congress of Roman Frontier Studies, Ruse, Bulgaria, September 2012, (ed.) L. Vagalinski, N. Sharankov, Sofia: 681-686.

Jeremić, M. 2001

Brick Kilns in Sirmium, Старинар L/2000: 7-11.

Jevtović, Lj. 2013.

Nalazi opeka sa pečatom VII Klaudijeve legije na teritoriji provincije Gornje Mezije, Unpublished master thesis, Faculty of Philosophy, University of Belgrade.

\section{Јордовић, Ч. 1994}

Грнчарски и цигларски центар у Виминацијуму, Саопитењ а XXVI: 95-105.

Јовановић, А. 2000

Нумизматичке белешке уз култ подунавских коњаника, Нумизматичар 21 (1998): 11-27.

\section{Korać, M. 1995}

Žišci sa teritorije Viminacijuma, Unpublished doctoral dissertation, Faculty of Philosophy, University of Belgrade.

\section{Korać, M. 2007}

Slikarstvo Viminacijuma, The Paintings of Viminacium, Beograd.

Korać, M., Golubović, S. i Mrđić, N. 2009

Itinerarium Romanum Serbiae, Putevima rimskih imperatora, Beograd.

\section{Љамић-Валовић, Н. 1985}

Античка цигларска пећ у Чукујевцу, Зборник радова Народног музеја XV, Чачак: 21-30.

\section{Минић, Д. 1991}

Цигларска пећ из Сталаћа, Старинар XL-XLI: 309-315.

\section{Mirković, M. 1968}

Rimski gradovi na Dunavu u Gornjoj Meziji, Beograd.

\section{Mirković, M. 1986}

Inscriptions de la Mésie Supérieure, Vol. II, Viminacium et Margum, Beograd.

\section{Pejović, Z. 1995}

Terakote iz zbirke muzeja Srema, Zbornik muzeja Srema 1: 37-62

Premk, A. 1994-1995

Terra-Cotta, Animal Figurines from Viminacium, Старинар XLV-XLVI: 143-155. 
Ненадовић, С. М., Јуришић, А. 1956

Археолошки радови, Римске циглане у Новом Костолцу, Саопштења I: 129-130.

\section{Nikolić, E. 2013}

Contribution to the study of Roman architecture in Viminacium: construction materials and building techniques, Arheologija i Prirodne nauke 8 (2012): 21-48.

\section{Radman-Livaja, I. 2004}

Militaria Sisciensia, nalazi vojne opreme iz Siska u fundusu Arheološkog muzeja u Zagrebu, Zagreb.

\section{Raičković, A., Redžić, S. 2006}

Keramičke i opekarske peći Viminacijuma - Lokacije „Pećine” i „Livade kod ćuprije”, Arheologija i Prirodne nauke 1: 81-106.

\section{Raičković, A., Redžić, S., Rogić, D. 2006}

Terakote sa prostora zanatskog centra Viminacijuma, Arheologija i prirodne nauke 2, (2006): 77-86.

\section{Raičković, A. 2007}

Keramičke posude zanatskog centra iz Viminacijuma, Arheologija i prirodne nauke, posebna izdanja 3, Beograd.

\section{Raičković, A., Vuković, S. 2009}

Keramičarska peć sa istočne nekropole Viminacijuma, Arheologija i Prirodne nauke 4 (2008): 81106.

\section{Raičković, A., Milovanović, B. 2010}

Rezultati istraživanja jugozapadnog dela lokaliteta Pirivoj (Viminacijum), Arheologija i Prirodne nauke 5 (2009): 7-56.

\section{Решић, С. 2008}

Извештај о археолошким истраживањима локалитета Пиривој, Виминацијум, у 2005. години, Археолошки Преглед 2/3 (2004/2005): 59-60.

\section{Redžić, S. 2007}

Nalazi rimskih fibula na nekropolama Viminacijuma, Beograd.

\section{Redžić, S. 2013}

Rimske pojasne garniture na tlu Srbije od I do IV veka, Unpublished doctoral dissertation, Faculty of Philosophy, University of Belgrade.

Спасић-Ђурић, Д. 2002

Виминацијум, главни град римске провинције Горье Мезије, Пожаревац.

\section{Валтровић, М. 1884}

Откопавања у Костолцу, Старинар 1, 3. део: 89-104.

Veličković, M. 1957

Katalog grčkih i rimskih terakota, Beograd.

\section{Vujović, M. 2013}

Roman Weapons and Military Equipment from Singidunum, Vesnik 40: 29-48.

\section{Vuković, S. 2010}

Ostaci životinja sa jugozapadnog dela lokaliteta Pirivoj (Viminacijum), Arheologija i Prirodne nauke 5 (2009): 57-82. 


\section{REZIME \\ RIMSKA CIGLARSKA PEĆ \\ SA ISTOČNE NEKROPOLE VIMINACIJUMA}

\section{KLJUČNE REČI: CIGLARSKA PEĆ, PROIZ- VODNJA OPEKA, PIRIVOJ, VIMINACIUM, III VEK NOVE ERE.}

Prilikom izgradnje vodovodne mreže za potrebe arheološkog parka Viminacijum 2013. godine došlo se do otkrića ciglarske peći na lokaciji Pirivoj. Peć se nalazila na prostoru istočne gradske nekropole. Više ciglarskih peći je otkriveno na Viminacijumu tokom zaštitnih iskopavanja južnih gradskih nekropola, 80-ih godina 20. veka, a tri peći istražene su na lokalitetu Pećine u okviru Zanatskog centra. Novootkrivena peć na lokalitetu Pirivoj građena je od nepečene cigle i blatnog maltera, uz minimalnu upotrebu opeke. Pripada tipu peći sa jednim ložišnim kanalom. Ložište i rešetka peći očuvani su u većoj meri, a od komore za pečenje samo delimično zidovi u visini od 70 $\mathrm{cm}$. Lučnog zasvedeni otvor ložišta nalazio se na zapadnoj strani. Na osnovu slojeva unutar peći, mogu se izdvojiti dve faze korišćenja. Ispod podnice ložišta peći je pronađen antički bunar koji je korišćen u vremenu pre njene izgradnje. Peć se na osnovu pokretnog materijala datuje u III i početak IV veka. 


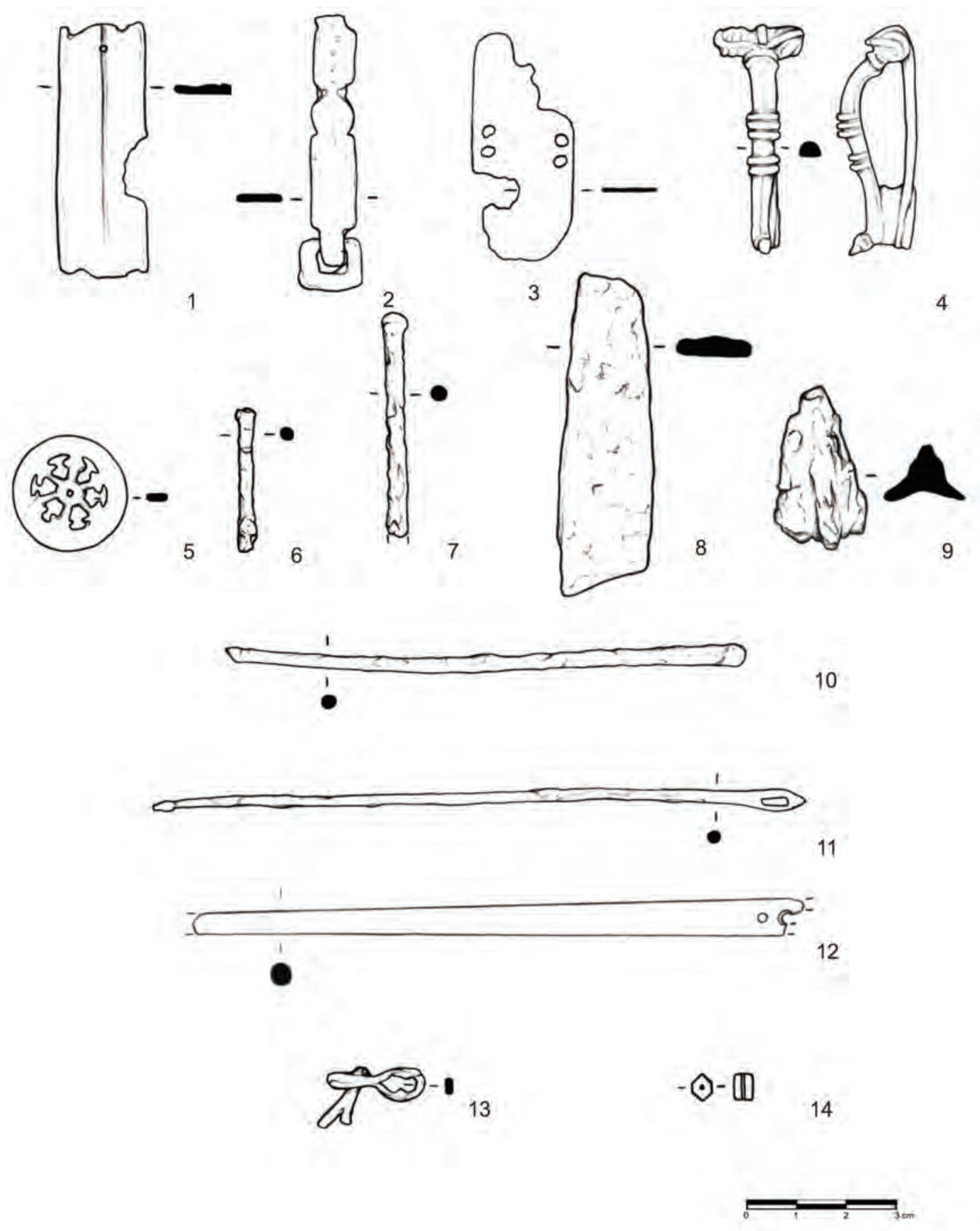

T. I. Finds from layer: fig. 1-8; 10-11; 13-14. Finds from pit 2: fig. 9; 12. 


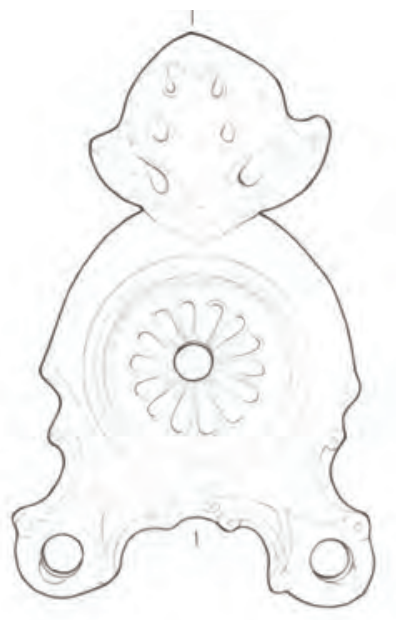

15
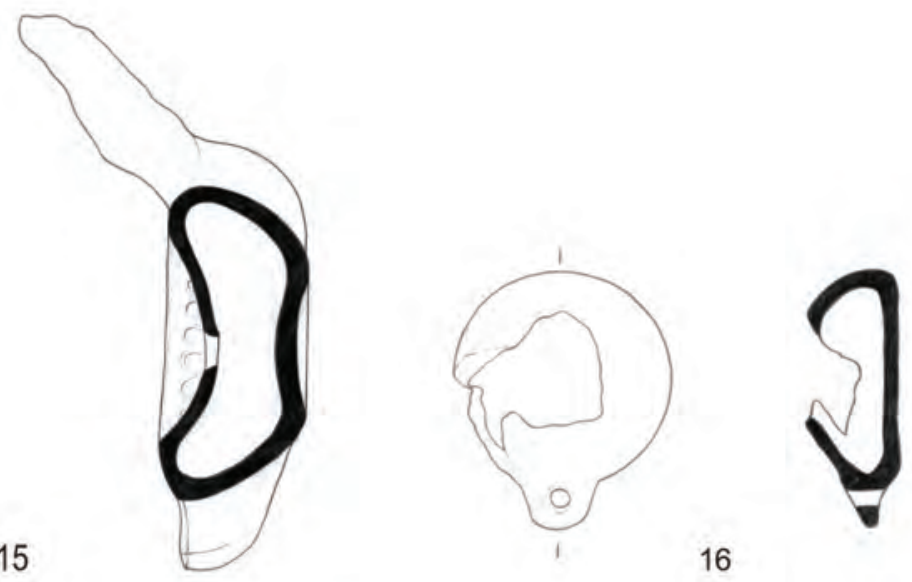

16

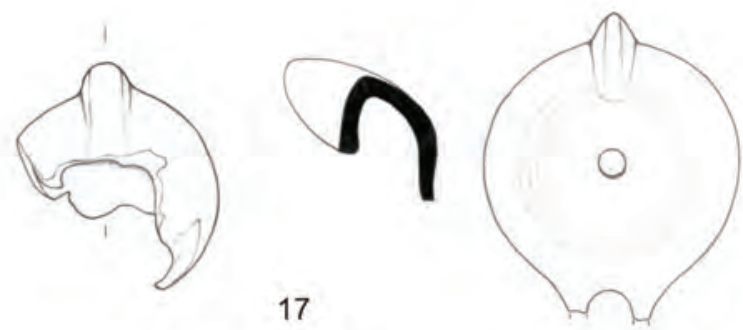

18
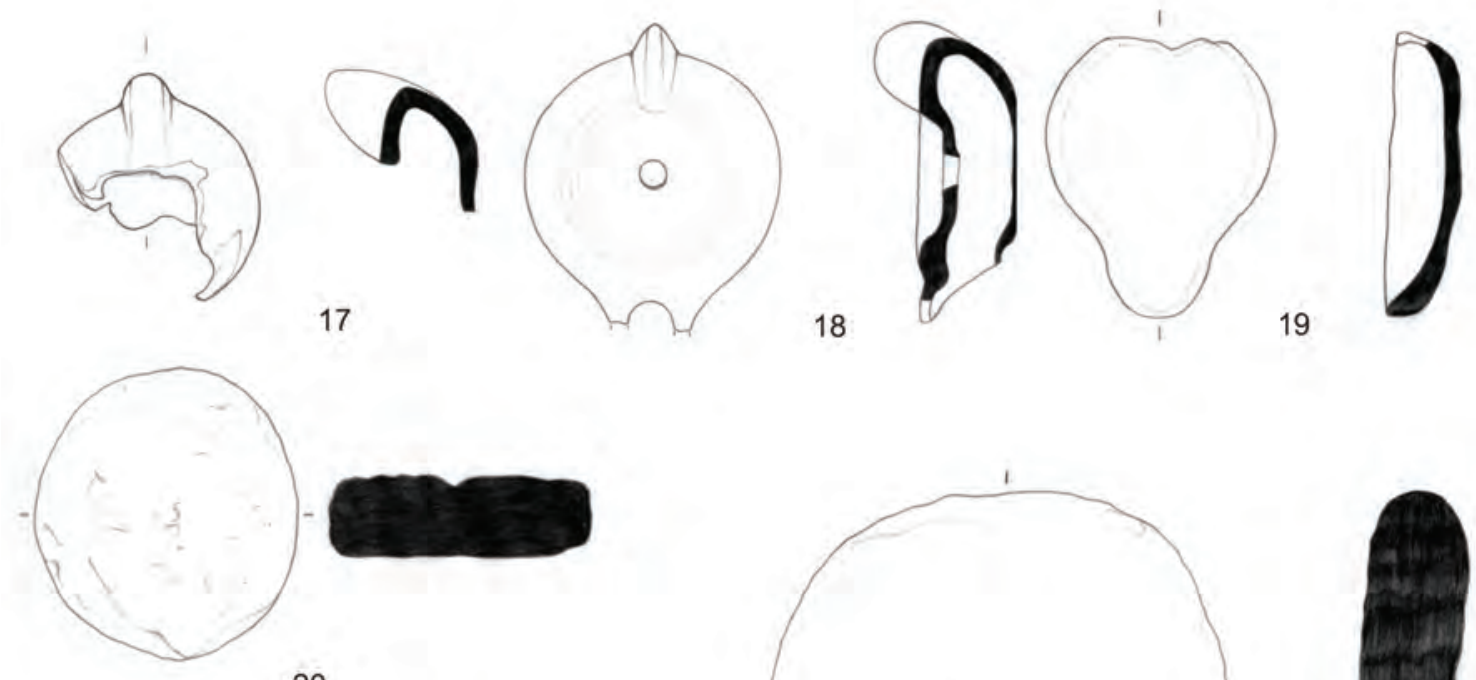

20
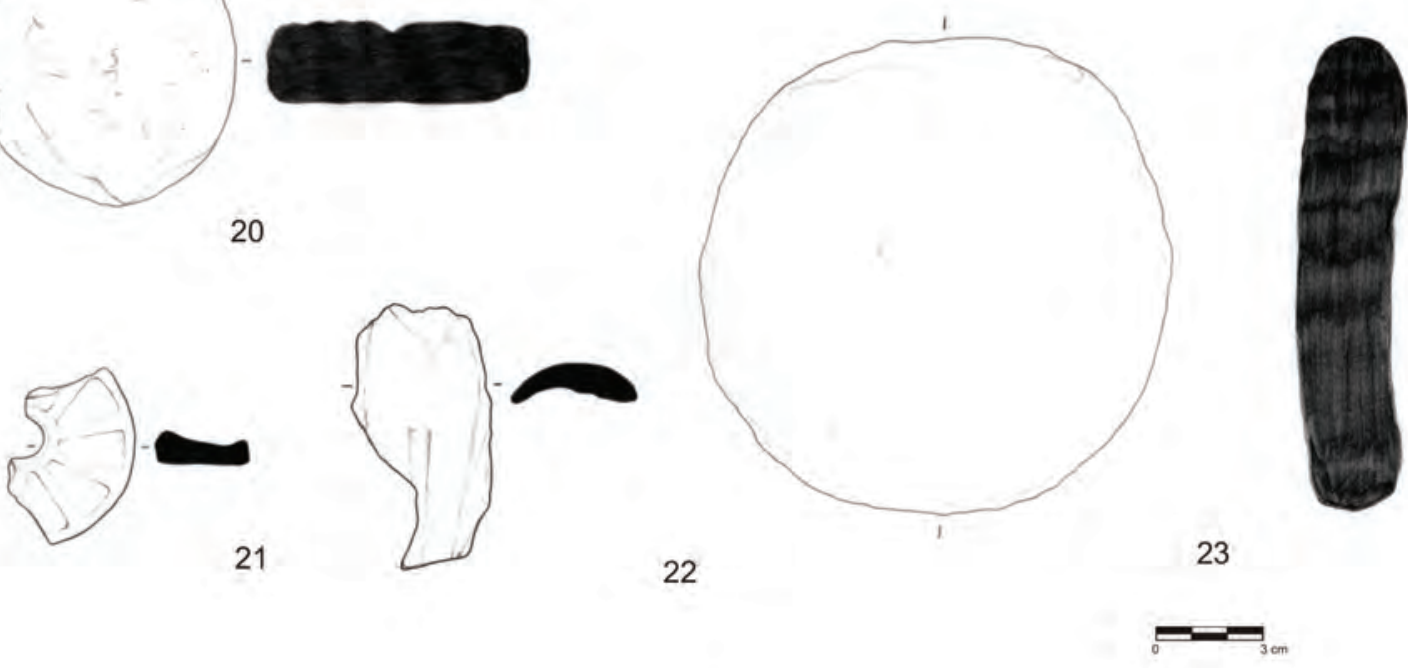

21

22

T. II. Lamps and other clay finds from layer. 